\title{
Clinical heterogeneity and diagnostic delay of autoimmune polyendocrinopathy-candidiasis-ectodermal dystrophy syndrome
}

Cinzia Mazza a ${ }^{\text {, Fabio Buzi }}{ }^{\text {a }}$, Federica Ortolani ${ }^{a}$, Alberto Vitali ${ }^{\text {, }}$ Lucia D. Notarangelo ${ }^{a}$, Giovanna Weber ${ }^{b}$, Rosa Bacchetta ${ }^{c}$, Annarosa Soresina ${ }^{a}$, Vassilios Lougaris ${ }^{a}$, Nella A. Greggio ${ }^{d}$, Andrea Taddio ${ }^{\mathrm{e}}$, Srdjan Pasic ${ }^{f}$, Monique de Vroede ${ }^{g}$, Malgorzata Pac ${ }^{h}$, Sara Sebnem Kilic ${ }^{i}$, Sanal Ozden ${ }^{j}$, Roberto Rusconi ${ }^{k}$, Silvana Martino', Donatella Capalbo ${ }^{\mathrm{m}}$, Mariacarolina Salerno $^{m}$, Claudio Pignata ${ }^{m}$, Giorgio Radetti ${ }^{n}$, Giuseppe Maggiore ${ }^{\circ}$, Alessandro Plebani ${ }^{a}$, Luigi D. Notarangelo $^{a}$, Raffaele Badolato ${ }^{a, *}$

\footnotetext{
a "A. Nocivelli" Institute for Molecular Medicine, Pediatric Clinic, University of Brescia, and Laboratory of Genetic Disease of Childhood, Spedali Civili, Brescia, Italy

b Centro di Endocrinologia dell'Infanzia e dell'Adolescenza, U.O. Pediatria e Neonatologia, Università Vita-Salute San Raffaele Milano, Italy

c San Raffaele Telethon Institute for Gene Therapy (HSR-TIGET), San Raffaele Scientific Institute, Milan Italy

${ }^{\mathrm{d}}$ Responsabile Diagnosi Prenatale Malattie genetico-endocrinologiche e collabora nella conduzione del Servizio di Endocrinologia, Diabetologie e Adolescentologia Pediatrica, Università di Padova, Italy

e Clinica Pediatrica, IRCCS Burlo Garofolo, Trieste, Italy

${ }^{f}$ Mother and Child Health Institute, Medical School, Univ. of Belgrade, Serbia

${ }^{9}$ WKZ, Utrecht University Children's Hospital, The Netherlands

${ }^{\mathrm{h}}$ Department of Immunology, Children's Memorial Health Institute, Warsaw, Poland

' Uludag University Medical Faculty Department of Pediatrics, Gorukle-Bursa, Turkey

${ }^{j}$ Departments of Pediatrics, Hacettepe University Faculty of Medicine, Ankara, Turkey

k IRCCS Policlinico- Cà Granda II Clinica Ped, Milano, Italy

' Dipartimento di Immunologia, Reumatologia e Malattie Infettive,

Università degli Studi di Torino Ospedale Infantile Regina Margherita, Italy

m Department of Pediatrics, University of Naples "Federico II," Naples, Italy

"Department of Pediatrics, Regional Hospital of Bolzan, Italy

- Dipartimento di Medicina della Procreazione e dell'Età Evolutiva, Università di Pisa, Pisa, Italy
}

Received 21 November 2010; accepted with revision 30 December 2010 Available online 3 February 2011

\footnotetext{
* Corresponding author. Istituto di Medicina Molecolare "Angelo Nocivelli", Universita' di Brescia, c/o Spedali Civili, 25123 Brescia, Italy. Fax: +390303388099 .

E-mail address: badolato@med.unibs.it (R. Badolato).
} 


\section{KEYWORDS}

Autoimmunity; Candidiasis;

Endocrinopathy

\begin{abstract}
Autoimmune polyendocrinopathy-candidiasis-ectodermal dystrophy (APECED) is a rare autosomal recessive organ-specific autoimmune disorder that is characterized by a variable combination of (i) chronic mucocutaneous candidiasis, (ii) polyendocrinopathy and/or hepatitis and (iii) dystrophy of the dental enamel and nails.

We analyzed the AIRE (autoimmune regulator) gene in subjects who presented any symptom that has been associated with APECED, including candidiasis and autoimmune endocrinopathy.

We observed that $83.3 \%$ of patients presented at least two of the three typical manifestations of APECED, while the remaining $16.7 \%$ of patients showed other signs of the disease.

Analysis of the genetic diagnosis of these subjects revealed that a considerable delay occurs in the majority of patients between the appearance of symptoms and the diagnosis. Overall, the mean diagnostic delay in our patients was 10.2 years. These results suggest that molecular analysis of AIRE should be performed in patients with relapsing mucocutaneous candidiasis for early identification of APECED.

(c) 2011 Elsevier Inc. All rights reserved.
\end{abstract}

\section{Introduction}

Autoimmune polyendocrinopathy-candidiasis-ectodermal dystrophy (APECED; MIM\# 240300) is a rare autosomal recessive disorder that was originally identified in selected populations through the typical association of mucocutaneous candidiasis with Addison's disease and hypoparathyroidism $[1,2]$. Although these symptoms usually constitute the first manifestation of the disease in early childhood, APECED patients often display other endocrine and nonendocrine disorders throughout their lifetimes, including thyroiditis, autoimmune hypogonadism, hypophysitis, chronic active hepatitis, atrophic gastritis, pernicious anemia, vitiligo, alopecia and ectodermal dystrophy [1-3].

Some genetically distinct populations, including Finns, Iranian Jews and Sardinians, display elevated prevalences (varying from 1 in 25,000 to 1 in 9,000) of this disease [4-9]. Localization of the APECED gene to chromosome 21 (21q22.3) in linkage analysis in the Finnish population, Iranian Jews and non-Finnish patients from other European countries led to the identification of the AIRE gene in this region [4,6-8]. AIRE encodes a 545 -amino acid protein of $58 \mathrm{kDa}$ that is characterized by an N-terminal HSR domain, two PHD-zinc fingers, LXXLL motifs and a SAND domain; the protein is expressed by medullary thymic epithelial cells (mTEC) and cells of the monocyte-dendritic cell lineage of the thymus $[10,11]$.

To investigate the natural history of APECED and the problems related to the diagnosis of sporadic forms of the disease, we investigated the clinical features of APECED in 24 patients with homozygous and/or composite heterozygous mutations of AIRE.

\section{Subjects and methods}

The study was approved by the Institutional Review Board of Spedali Civili, Brescia, and informed consent was obtained from the parents of the studied children. Blood samples with EDTA or heparin were collected from patients who presented with candidiasis and/or autoimmune endocrinopathy. Genetic analysis was performed in 225 subjects: AIRE mutations were identified in 38 subjects, while
14 patients showed heterozygous mutations. A molecular analysis of the AIRE gene was performed by direct sequencing as follows: genomic DNA was extracted from peripheral blood; all 14 exons of the AIRE gene were amplified using primers located on the respective flanking introns [15], and the amplification products were analyzed by direct sequencing using the ABI PRISM 3130 sequencer (Applied Biosystems, Foster City, CA). The analysis included sequences of the donor/acceptor sites of all of the introns (primers available upon request). Diagnosis of APECED was based on the identification of homozygous mutations or composite heterozygous mutations of AIRE. Clinical features of APECED patients were collected using a form sent to the referring physicians.

\section{Results}

\subsection{Molecular analysis of the AIRE gene}

We evaluated the genetic, immunological and clinical features of 24 patients who were referred to our center for genetic analysis of AIRE. The mean age of the patients was 16.5 years (range: 2-41 years). The majority of these patients (19 subjects) were from Italy, but none of them were from Sardinia; two patients were from Turkey, two patients were from Holland and one patient was from Poland. All 14 exons of the AIRE gene, including the $5^{\prime}$ and $3^{\prime}$ flanking regions of the corresponding introns, were individually sequenced in each of the 24 APECED patients. In these subjects, we identified 14 mutations, 4 of which have not been reported previously (L87P, C457fs, C449X and the complex mutation IVS $8+3 \mathrm{G}>\mathrm{T} ;+5 \mathrm{G}>\mathrm{T}$ ) (Table 1). In particular, homozygous mutations were detected in $37.5 \%$ of the patients, whereas $62.5 \%$ of the patients had compound heterozygous mutations.

The most frequent mutation was the non-sense mutation R257X, which occurred in $5(20.8 \%)$ patients in a homozygous state and in another $5(20.8 \%)$ in a single allele. The frequency of this mutation in the studied cohort was $41.6 \%$. The R139X mutation, which is typical of Sardinian patients, was detected in two patients in the heterozygous state. We identified at least one mutation in the first two exons (HSR 
domain) of the AIRE gene in $50 \%$ of the patients, whereas $41.6 \%$ of our population showed a mutation in exons 5 and 6 (SAND domain).

\subsection{Clinical and immunological features}

In our 24 patients, the first manifestation of APECED was observed in childhood at a mean age of 4 years (range: $1-$ 13.7 years). At least one of the three most common manifestations (hypoparathyroidism, mucocutaneous candidiasis and adrenal failure) appeared by 13.7 years of age in $83 \%$ of cases. Among them, five patients developed two major clinical manifestations by 6.7 years of age. In contrast, four patients showed atypical manifestations as the first expression of the disease, including one case of ovarian failure, one case of nail dystrophy and two cases of autoimmune hepatitis (Table 2). In the following years, $37.5 \%$ of our patients developed all three major clinical manifestations, while $45.8 \%$ of APECED patients showed at least two of the three manifestations. One patient presented with chronic hypoparathyroidism after presenting with ovarian failure. Another patient with ovarian failure also developed hypoparathyroidism and occasional candidiasis. One patient developed candidiasis followed by nail dystrophy and autoimmune hypothyroidism. One patient did not develop any of the three major manifestations, showing only vitiligo, nail dystrophy and autoimmune gastritis.

Immunological studies including analysis of immunoglobulin levels and of lymphocyte subpopulations were normal. In particular, IgG (range: $600-2120 \mathrm{mg} / \mathrm{dl}$ ), IgA (range: 40 $166 \mathrm{mg} / \mathrm{dl}$ ), IgM (range: 44-209) were usually in the normal range, or increased in some patients.

The three main manifestations of APECED occurred in the following chronological order: mucocutaneous candidiasis (mean age of onset: 2.5 years and maximum incidence in the 1st year of life); hypoparathyroidism (mean age of onset: 5.9 years and maximum incidence in the 6th year); and adrenal failure (mean age of onset: 8 years and maximum incidence in the 9 th year). During their life spans, $75 \%$ of the APECED patients developed candidiasis, which appeared when patients were between 1 month and 19 years of age. In $41.7 \%$ of them, candidiasis was the first manifestation of APECED. Hypoparathyroidism was the first endocrine manifestation to occur. It was present in $83 \%$ of patients and developed when they were between 2 and 29 years of age. Addison's disease was observed in $62 \%$ of cases, appearing between 2 and 13 years of age.

Ectodermal dystrophy appeared in almost half of the patients and always involved the nails. The mean age of onset of this disorder (8 years) overlapped with that of Addison's disease (peak age of onset between 7 and 9 years). Vitiligo and alopecia were observed in $29 \%$ and $20 \%$ of cases, respectively. Autoimmune hepatitis was observed in $25 \%$ of our patients, occurring before 3 years of age or after 20 years of age.

Approximately $25 \%$ of patients developed autoimmune thyroiditis (mean age of onset: 8.9 years). Other uncommon clinical manifestations of APECED included pernicious anemia, ovarian failure, keratoconjunctivitis, type 1 diabetes and encephalitis (Table 2).
A considerable delay between the appearance of symptoms and the diagnosis of the disease was observed in the majority of patients. Among the APECED patients, 17 subjects presented the first clinical manifestation within 5 years of age, and the mean diagnostic delay was 11.9 years (Fig. 1). In the other 7 patients, who presented the first symptom of the disease after 5 years of age, the mean diagnostic delay was 5.9 years. Overall, the mean diagnostic delay in our patients was 10.2 years. The broad heterogeneity in the clinical manifestations that were observed at the onset may account for the length of time between the first clinical manifestation of APECED and the time of diagnosis.

\section{Discussion}

APECED is a very rare genetic disorder, but some distinct populations (Finns, Iranian Jews and Sardinians) display an elevated prevalence of this disease. Indeed, many articles describing this syndrome are related to selected populations $[5,9,12-19]$. Our study, however, is based on a heterogeneous group of 24 patients originating from Italy and other European countries. In this population, we have detected AIRE mutations that were previously reported in selected areas: R257X (with a frequency of 42\%), the W78R mutation (identified in 17\% of our cases), the 967-979 13 bp deletions (identified in $17 \%$ of our patients) and the R139X mutation (detected in two patients) [13]. Although we performed complete sequencing of the coding regions and splicing sites, we detected the majority of the mutations in the first two exons, which encode for the HSR domain of the AIRE gene, and in exons 5 and 6 , which encode for the SAND domain. Evaluation of the clinical features of these patients did not reveal any genotype/phenotype correlation.

Indeed, study of the clinical manifestations of APECED in our series of patients revealed an extreme heterogeneity in symptoms and in the age of first appearance of the disease. Although the first manifestation of APECED usually occurred in childhood, the age of onset (ranging from 1 to 13.7 years) was extremely variable among our patients. Moreover, despite the assumption that APECED diagnosis requires the identification of at least two of three major clinical manifestations (chronic mucocutaneous candidiasis, hypoparathyroidism and adrenal failure), only $83.3 \%$ of our patients satisfied these criteria, while the remaining four patients developed distinct signs of APECED at the appearance of the disease. In particular, autoimmune hepatitis was observed in two patients, ovarian failure was observed in one case, and nail dystrophy was observed in another patient.

We have observed that development of candidiasis unresponsive to topical antifungal therapy constitutes an alerting sign of APECED and occurs earlier than endocrine manifestations. This observation further supports the notion that in patients who present with relapsing candidiasis, despite the antifungal therapy, within 3 years of age should be subjected to screening for primary immunodeficiencies and to genetic analysis of AIRE. Implementation of this recommendation could help in the identification of APECED patients before the acute development of endocrine manifestations of the disease. 
Table 1 Genetic analysis of AIRE in 24 APECED patients.

\begin{tabular}{|c|c|c|c|c|c|c|c|c|}
\hline ID & $\begin{array}{l}\text { City, } \\
\text { country }\end{array}$ & $\begin{array}{l}\text { Familial } \\
\text { case }\end{array}$ & Mutation & cDNA nucl & Ex. & Protein effect & Allele $1^{*}$ & Allele $2^{*}$ \\
\hline 1 & Milan, IT & No & Homozygous & 260 & 2 & L87P & $\mathbf{T}>\mathbf{C}$ & $\mathbf{T}>\mathbf{C}$ \\
\hline 2 & Padova, IT & No & Homozygous & 769 & 6 & R257X & $\mathrm{C}>\mathrm{T}$ & $\mathrm{C}>\mathrm{T}$ \\
\hline 3 & Brescia, IT & $\begin{array}{l}\text { Yes } \\
\text { (3 and 4) }\end{array}$ & $\begin{array}{l}\text { Compound } \\
\text { heterozygous }\end{array}$ & $607 / 769$ & $5 / 6$ & {$[R 203 X]+[R 257 X]$} & $\mathrm{C}>\mathrm{T}$ & $\mathrm{C}>\mathrm{T}$ \\
\hline 4 & Brescia, IT & $\begin{array}{l}\text { Yes } \\
\text { (3 and } 4)\end{array}$ & $\begin{array}{l}\text { Compound } \\
\text { heterozygous }\end{array}$ & $607 / 769$ & $5 / 6$ & {$[R 203 X]+[R 257 X]$} & $\mathrm{C}>\mathrm{T}$ & $\mathrm{C}>\mathrm{T}$ \\
\hline 5 & Torino, IT & No & $\begin{array}{l}\text { Compound } \\
\text { heterozygous }\end{array}$ & 260/967-979 & $2 / 8$ & {$[\mathrm{~L} 87 \mathrm{P}]+[\mathrm{C} 322 \mathrm{fs}]$} & $\mathrm{T}>\mathrm{C}$ & Del13bp \\
\hline 6 & NL & $\begin{array}{l}\text { Yes } \\
\text { (6 and 7) }\end{array}$ & Homozygous & 769 & 6 & R257X & $C>T$ & $C>T$ \\
\hline 7 & NL & $\begin{array}{l}\text { Yes } \\
\text { (6 and 7) }\end{array}$ & Homozygous & 769 & 6 & R257X & $C>T$ & $\mathrm{C}>\mathrm{T}$ \\
\hline 8 & Turkey & No & Homozygous & 769 & 6 & R257X & $\mathrm{C}>\mathrm{T}$ & $\mathrm{C}>\mathrm{T}$ \\
\hline 9 & Torino, IT & No & $\begin{array}{l}\text { Compound } \\
\text { heterozygous }\end{array}$ & $260 / 1616$ & $2 / 14$ & [L87P] + [P539L] & $\mathrm{T}>\mathrm{C}$ & $\mathrm{C}>\mathrm{T}$ \\
\hline 10 & Trieste, IT & $\begin{array}{l}\text { Yes } \\
(10 \text { and } 11)\end{array}$ & Homozygous & 232 & 2 & W78R & $\mathrm{T}>\mathrm{C}$ & $\mathrm{T}>\mathrm{C}$ \\
\hline 11 & Trieste, IT & $\begin{array}{l}\text { Yes } \\
(10 \text { and } 11)\end{array}$ & Homozygous & 232 & 2 & W78R & $\mathrm{T}>\mathrm{C}$ & $\mathrm{T}>\mathrm{C}$ \\
\hline 12 & Napoli, IT & No & $\begin{array}{l}\text { Compound } \\
\text { heterozygous }\end{array}$ & 62/967-979 & $1 / 8$ & {$[\mathrm{~A} 21 \mathrm{~V}]+[\mathrm{C} 322 \mathrm{fs}]$} & $\mathrm{C}>\mathrm{T}$ & Del13bp \\
\hline 13 & Milan, IT & No & $\begin{array}{l}\text { Compound } \\
\text { heterozygous }\end{array}$ & 769/967-979 & $6 / 8$ & {$[R 257 X]+[C 322 f s]$} & $\mathrm{C}>\mathrm{T}$ & Del13bp \\
\hline 14 & Poland & No & Homozygous & 769 & 6 & $\mathrm{R} 257 \mathrm{X}$ & $\mathrm{C}>\mathrm{T}$ & $\mathrm{C}>\mathrm{T}$ \\
\hline 15 & Turkey & No & $\begin{array}{l}\text { Compound } \\
\text { heterozygous }\end{array}$ & 769/1370-1371 & $6 / 11$ & {$[\mathrm{R} 257 \mathrm{X}]+[\mathrm{C} 457 \mathrm{fs}]$} & $\mathrm{C}>\mathrm{T}$ & insG \\
\hline 16 & Brescia, IT & No & $\begin{array}{l}\text { Compound } \\
\text { heterozygous }\end{array}$ & $415 / 769$ & $3 / 6$ & {$[R 139 X]+[R 257 X]$} & $\mathrm{C}>\mathrm{T}$ & $\mathrm{C}>\mathrm{T}$ \\
\hline 17 & Milano, IT & No & $\begin{array}{l}\text { Compound } \\
\text { heterozygous }\end{array}$ & IVS1/IVS8 & $1 / 8$ & Splicing mutation & $\begin{array}{l}+1 G>C \\
+5 \text { delG }\end{array}$ & $\begin{array}{l}+3 G>T \\
+5 G>T\end{array}$ \\
\hline 18 & Pisa, IT & No & $\begin{array}{l}\text { Compound } \\
\text { heterozygous }\end{array}$ & $967-979 / 1347$ & $8 / 11$ & [C322fs] + [C449X] & Del13bp & $\mathbf{C}>\mathbf{A}$ \\
\hline 19 & Napoli, IT & No & Homozygous & IVS1 & 1 & Splicing mutation & $\begin{array}{l}+1 G>C \\
+5 \text { delG }\end{array}$ & $\begin{array}{l}+1 \mathrm{G}>\mathrm{C} \\
+5 \mathrm{del} G\end{array}$ \\
\hline 20 & Milano, IT & No & $\begin{array}{l}\text { Compound } \\
\text { heterozygous }\end{array}$ & 232/IVS8 & $2 / 8$ & [W78R]+ [splicing mutation] & $\mathrm{T}>\mathrm{C}$ & $\begin{array}{l}+3 \mathrm{G}>\mathrm{T} \\
+5 \mathrm{G}>\mathrm{T}\end{array}$ \\
\hline 21 & Napoli, IT & No & $\begin{array}{l}\text { Compound } \\
\text { heterozygous }\end{array}$ & $47 / 232$ & $1 / 2$ & [T16M] + [W78R] & $\mathrm{C}>\mathrm{T}$ & $\mathrm{T}>\mathrm{C}$ \\
\hline 22 & Brescia, IT & No & $\begin{array}{l}\text { Compound } \\
\text { heterozygous }\end{array}$ & $47 / 62$ & 1 & {$[\mathrm{~T} 16 \mathrm{M}]+[\mathrm{A} 21 \mathrm{~V}]$} & $\mathrm{C}>\mathrm{T}$ & $\mathrm{C}>\mathrm{T}$ \\
\hline 23 & Napoli, IT & No & $\begin{array}{l}\text { Compound } \\
\text { heterozygous }\end{array}$ & 62/967-979 & $1 / 8$ & {$[\mathrm{~A} 21 \mathrm{~V}]+[\mathrm{C} 322 \mathrm{fs}]$} & $\mathrm{C}>\mathrm{T}$ & Del13bp \\
\hline 24 & Milano, IT & No & $\begin{array}{l}\text { Compound } \\
\text { heterozygous }\end{array}$ & 415/905-906 & $3 / 8$ & {$[\mathrm{R} 139 \mathrm{X}]+[\mathrm{C} 302 \mathrm{fs}]$} & $C>T$ & DelGT \\
\hline
\end{tabular}

Although a large majority of APECED patients show typical symptoms of the disease in their first decade of life, diagnosis is often delayed until the second decade of life. We speculate that this unexpected hindrance in the genetic diagnosis of APECED is related to the poor availability of AIRE genetic testing in European countries. In addition, the identification of APECED may be difficult in patients who present at the onset with non-endocrine manifestations of the disease. Because delayed diagnosis of APECED can be associated with severe manifestations of the disease, such as Addison's disease and autoimmune hepatitis, it would be appropriate to increase the availability of genetic testing of AIRE and to improve awareness about this rare disorder among pediatricians and endocrinologists.

\section{Acknowledgments}

This work was supported by grants from Fondazione Cariplo NOBEL Grant, EU Grant FP7 HLH-cure (project no. 201461), and PRIN 2007 no. 2007ACZMMZ_005 to RB. 
Table 2 Clinical manifestations in 24 APECED patients.

\begin{tabular}{|c|c|c|c|c|c|c|c|c|c|c|c|c|c|c|c|c|c|c|c|c|c|c|c|c|}
\hline $\mathrm{Pt}$ & 1 & 2 & 3 & 4 & 5 & 6 & 7 & 8 & 9 & 10 & 11 & 12 & 13 & 14 & 15 & 16 & 17 & 18 & 19 & 20 & 21 & 22 & 23 & 24 \\
\hline \multicolumn{25}{|l|}{ Candidiasis } \\
\hline \multicolumn{25}{|c|}{ Hypoparathyroidism } \\
\hline \multicolumn{25}{|c|}{ Addison disease } \\
\hline \multicolumn{25}{|c|}{ Nail dystrophy } \\
\hline \multicolumn{25}{|l|}{ Alopecia } \\
\hline \multicolumn{25}{|l|}{$\begin{array}{l}\text { Autoimmune } \\
\text { hepatitis }\end{array}$} \\
\hline \multicolumn{25}{|l|}{ Vitiligo } \\
\hline \multicolumn{25}{|l|}{$\begin{array}{l}\text { Autoimmune } \\
\text { thyroiditis }\end{array}$} \\
\hline \multicolumn{25}{|c|}{ Pernicious anemia } \\
\hline \multicolumn{25}{|c|}{ Hypogonadism } \\
\hline \multicolumn{25}{|l|}{ Keratitis } \\
\hline \multicolumn{25}{|c|}{ Autoimmune gastritis } \\
\hline \multicolumn{25}{|c|}{$\begin{array}{l}\text { Insulin-dependent } \\
\text { diabetes mellitus }\end{array}$} \\
\hline Encephalitis & & & & & & & & & & & & & & & & & & & & & & & & \\
\hline
\end{tabular}

The first row of the table reports the patient identification number. For each patient, the appearance of specific manifestation is marked in grey.

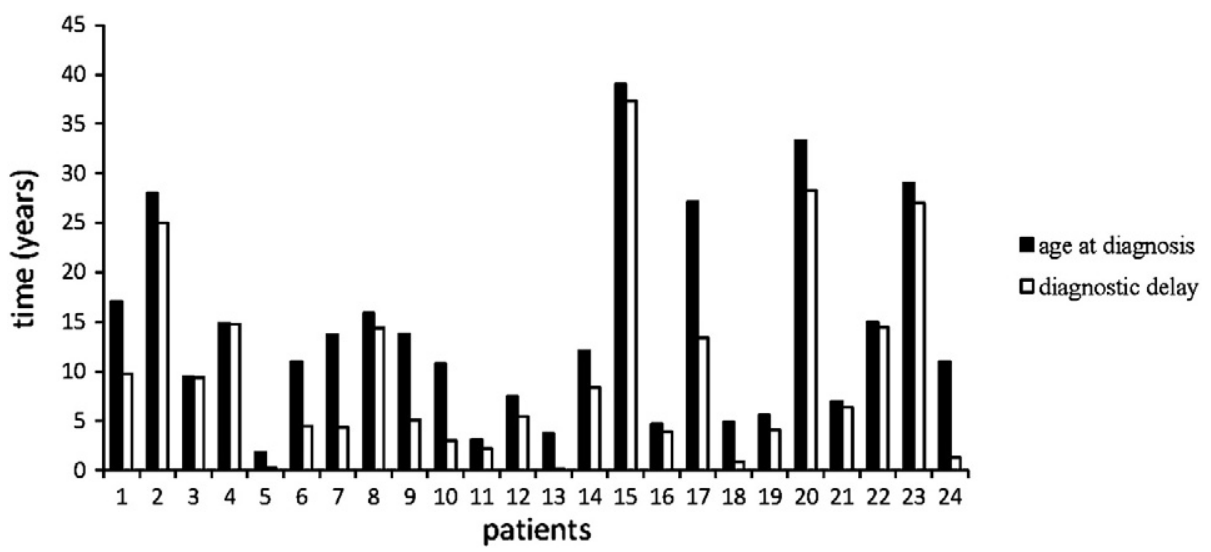

Figure 1 Diagnostic delay of genetic diagnosis of APECED in 24 patients. For each patient, the age at diagnosis (black column) and the diagnostic delay (white column), calculated as the difference between the diagnosis and the observation of the first symptom, are reported on the y axis.

\section{References}

[1] D. Moraes-Vasconcelos, B.T. Costa-Carvalho, T.R. Torgerson, H.D. Ochs, Primary immune deficiency disorders presenting as autoimmune diseases: IPEX and APECED, J. Clin. Immunol. 28 (Suppl 1) (2008) S11-S19.

[2] A. Vogel, C.P. Strassburg, P. Obermayer-Straub, G. Brabant, M.P. Manns, The genetic background of autoimmune polyendocrinopathy-candidiasis-ectodermal dystrophy and its autoimmune disease components, J. Mol. Med. 80 (2002) 201-211.

[3] G.S. Eisenbarth, P.A. Gottlieb, Autoimmune polyendocrine syndromes, N. Engl. J. Med. 350 (2004) 2068-2079.
[4] J. Aaltonen, P. Bjorses, L. Sandkuijl, J. Perheentupa, L. Peltonen, An autosomal locus causing autoimmune disease: autoimmune polyglandular disease type I assigned to chromosome 21, Nat. Genet. 8 (1994) 83-87.

[5] J. Zlotogora, M.S. Shapiro, Polyglandular autoimmune syndrome type I among Iranian Jews, J. Med. Genet. 29 (1992) 824-826.

[6] P. Bjorses, J. Aaltonen, A. Vikman, J. Perheentupa, G. BenZion, G. Chiumello, N. Dahl, P. Heideman, J.J. HoorwegNijman, L. Mathivon, P.E. Mullis, M. Pohl, M. Ritzen, G. Romeo, M.S. Shapiro, C.S. Smith, J. Solyom, J. Zlotogora, L. Peltonen, Genetic homogeneity of autoimmune polyglandular disease type I, Am. J. Hum. Genet. 59 (1996) 879-886. 
[7] K. Nagamine, P. Peterson, H.S. Scott, J. Kudoh, S. Minoshima, M. Heino, K.J. Krohn, M.D. Lalioti, P.E. Mullis, S.E. Antonarakis, K. Kawasaki, S. Asakawa, F. Ito, N. Shimizu, Positional cloning of the APECED gene, Nat. Genet. 17 (1997) 393-398.

[8] The Finnish-German APECED Consortium, An autoimmune disease, APECED, caused by mutations in a novel gene featuring two PHD-type zinc-finger domains. The Finnish-German APECED Consortium. Autoimmune polyendocrinopathy-candidiasis-ectodermal dystrophy, Nat. Genet. 17 (1997) 399-403.

[9] M.C. Rosatelli, A. Meloni, M. Devoto, A. Cao, H.S. Scott, P. Peterson, M. Heino, K.J. Krohn, K. Nagamine, J. Kudoh, N. Shimizu, S.E. Antonarakis, A common mutation in Sardinian autoimmune polyendocrinopathy-candidiasis-ectodermal dystrophy patients, Hum. Genet. 103 (1998) 428-434.

[10] J. Pitkanen, P. Vahamurto, K. Krohn, P. Peterson, Subcellular localization of the autoimmune regulator protein. Characterization of nuclear targeting and transcriptional activation domain, J. Biol. Chem. 276 (2001) 19597-19602.

[11] M.S. Anderson, E.S. Venanzi, L. Klein, Z. Chen, S.P. Berzins, S.J. Turley, H. von Boehmer, R. Bronson, A. Dierich, C. Benoist, D. Mathis, Projection of an immunological self shadow within the thymus by the aire protein, Science 298 (2002) 1395-1401.

[12] P. Ahonen, S. Myllarniemi, I. Sipila, J. Perheentupa, Clinical variation of autoimmune polyendocrinopathy-candidiasis-ectodermal dystrophy (APECED) in a series of 68 patients, N. Engl. J. Med. 322 (1990) 1829-1836.

[13] M. Heino, P. Peterson, J. Kudoh, N. Shimizu, S.E. Antonarakis, H.S. Scott, K. Krohn, APECED mutations in the autoimmune regulator (AIRE) gene, Hum. Mutat. 18 (2001) 205-211.

[14] C. Betterle, C. Dal Pra, F. Mantero, R. Zanchetta, Autoimmune adrenal insufficiency and autoimmune polyendocrine syndromes: autoantibodies, autoantigens, and their applicability in diagnosis and disease prediction, Endocr. Rev. 23 (2002) 327-364.

[15] S.H. Pearce, T. Cheetham, H. Imrie, B. Vaidya, N.D. Barnes, R.W. Bilous, D. Carr, K. Meeran, N.J. Shaw, C.S. Smith, A.D. Toft, G. Williams, P. Kendall-Taylor, A common and recurrent 13-bp deletion in the autoimmune regulator gene in British kindreds with autoimmune polyendocrinopathy type 1, Am. J. Hum. Genet. 63 (1998) 1675-1684.

[16] A. Meloni, R. Perniola, V. Faa, E. Corvaglia, A. Cao, M.C. Rosatelli, Delineation of the molecular defects in the AIRE gene in autoimmune polyendocrinopathy-candidiasis-ectodermal dystrophy patients from Southern Italy, J. Clin. Endocrinol. Metab. 87 (2002) 841-846.

[17] M. Dominguez, E. Crushell, T. Ilmarinen, E. McGovern, S. Collins, B. Chang, P. Fleming, A.D. Irvine, D. Brosnahan, I. Ulmanen, N. Murphy, C. Costigan, Autoimmune polyendocrinopathy-candidiasis-ectodermal dystrophy (APECED) in the Irish population, J. Pediatr. Endocrinol. Metab. 19 (2006) 1343-1352.

[18] A.S. Wolff, M.M. Erichsen, A. Meager, N.F. Magitta, A.G. Myhre, J. Bollerslev, K.J. Fougner, K. Lima, P.M. Knappskog, E.S. Husebye, Autoimmune polyendocrine syndrome type 1 in Norway: phenotypic variation, autoantibodies, and novel mutations in the autoimmune regulator gene, J. Clin. Endocrinol. Metab. 92 (2007) 595-603.

[19] S. Cervato, B. Mariniello, F. Lazzarotto, L. Morlin, R. Zanchetta, G. Radetti, F. De Luca, M. Valenzise, R. Giordano, D. Rizzo, C. Giordano, C. Betterle, Evaluation of the autoimmune regulator (AIRE) gene mutations in a cohort of Italian patients with autoimmune-polyendocrinopathy-candidiasis-ectodermal-dystrophy (APECED) and in their relatives, Clin. Endocrinol.Oxf 70 (2009) 421-428. 